Снежана Ненезић

Народна библиотека Крушевац
UDC: 930.85:004(497.11)

DOI: $10.18485 /$ dh.2015.1.ch4

\title{
ИНСТИТУЦИЈЕ КУЛТУРЕ У ЕРИ ДИГИТАЛНЕ ХУМАНИСТИКЕ
}

\section{Сажетак}

Актуелни тренутак и високо развијено технолошко окружење унели су нову димензију у пословање институција културе, проширили простор, али су истовремено и наметнули традиционалним баштинским установама културе нове захтеве.

Предмет овог рада је компарација дигитализације збирки и њихове доступности на мрежи баштинских установа културе библиотека, музеја и архива у Србији.

Запослени у институцијама културе с једне стране корисници су дигиталних колекција у циљу професионалног усавршавања, допуњавања описа колекција, као и самих колекција дигиталним сурогатима, а с друге стране су и сами креатори садржаја институција у којима раде - дигиталних збирки.

Дигиталне копије додају нову вредност збиркама и захтевају другачије „читање слика“. Остварују се нове корелације са корисницима - читаоцима, гледаоцима, истраживачима.

Визуелизација збирки развила је нову естетику и нове врсте читања.

Истрживање веб сајтова културних институција у Србији пружа нам комплетну слику о заступљености различитих дигиталних колекција у мрежном окружењу, како и на који начин су збике представљене, доступне и колико су корисници упознати са постојањем истих.

Рад се бави и односом књиге, предмета и документа у посматраним збиркама.

Кључне речи: институције културе, дигитализација колекција, дигитална хуманистика

\section{Корисници и креатори дигиталних садржаја}

Дигиталне копије додају нову вредност збиркама и захтевају другачије „читање слика“. Остварују се нове корелације са корисницима - читаоцима, гледаоцима, истраживачима. Визуелизација збирки развила је нову естетику и нове врсте читања. Истрживање веб сајтова културних институција у Србији пружа нам слику о заступљености 
различитих дигиталних колекција у мрежном окружењу, како и на који начин су збике представљене, доступне и колико су корисници упознати са постојањем истих.

Према подацима објављеним у „Статистичком годишњаку за 2014. годину“ ${ }^{1}$ укупни број музеја у Србији је 145, од којих су 43 у Београдском региону, 34 у региону Јужне Војводине, 36 у региону Шумадије и Западне Србије и 27 региону Јужне и Источне Србије.

Број архива у Србији је 38 (2 републичка, 2 покрајинска, 34 градска и регионална) - податак из 2008. године. Број завода за заштиту споменика културе је 13 (1 републички, 2 покрајинска, 2 градска и 8 регионалних).

Мрежу јавних библиотека, као подсистем библиотечко-инфрмационог система Србије у 2014. години чиниле су следеће јединице: „151 самостална библиотека (у Војводини 41, у Централној Србији 110), 10 организационих јединица општинских домова културе које врше функцију општинске јавне библиотеке (у Војводини 4, у Централној Србији 6) , 350 стационираних органака јавних библиотека (186 у Војводини и 164 у Централној Србији), 30 месних библиотека (13 у Војводини и 17 у Централној Србији), 28 библиотека са општим фондом у предузећима (7 у Војводини и 21 у Централној Србији) и 3 покретна огранка - укупно 572 јединице (251 у Војводини и 321 у Централној Србији).“2

Најобимнија дигитална колекција у српским библиотекама је Дигитална Народна библиотека Србије која броји више од 1.200.000 дигитализованих страница у различитим колекцијама: новине, часописи, рукписна периодика, књиге, збирка ћирилских рукописних књига НБС, звучне књиге, стара штампана књига, стара и ретка књига, каталози и библиографије, библиотеке целине и легати, фотодокумента, нотна грађа, звучни снимци, плакати и документациони материјал, гравире и ликовни материјали, картографска грађа, народна поезија, завичајна збирка, стрипови и графичке новеле, тематске колекције - нпр. Велики

1 http://pod2.stat.gov.rs/ObjavljenePublikacije/G2014/pdfE/G20142013.pdf (доступно 30.06.2016.)

2 Мрежа јавних библиотека Србије у периоду од 2000. до 2014. године https://www. nb.rs/view_file.php?file_id=4417 (доступно 30.06.2016.) 
рат, књиге о ЕУ. Дигитална колекција „изграђена је у складу са принципима отвореног приступа знању и информацијама. Дигитализована грађа из колекција Народне библиотеке Србије представља јавно национално добро."з

Народна библиотека Србије је једна од 12 институција из осам земаља окупљених на пројекту Europeana Collections 1914-1918, како би се писано наслеђе Првог светског рата дигитализовало и учинило јавно доступним. Преко 460 докумената је доступно јавности, од тога из Србије преко 4.000 дигиталних објеката. У оквиру пројекта, НБС је покренула специјализовану дигиталну библиотеку Велики рат (velikirat.rs).

Следећа велика колекција Дигитална Библиотека Матице српске (Дигитална БМС) резултат је дигитализације која се одвија од 2006. године као део система заштите старих и ретких публикација у Одељењу заштите публикација, а у сарадњи са Одељењем старе и ретке књиге и легата. „Приоритет је дат публикацијама које су описане у редовним едицијама Ћирилске рукописне књиге БМС и Каталог cmaрих и ретких књига БМС као и издањима библиотеке. Дигитална БМС је данас једна од највећих дигиталних библиотека у Србији. Свакодневно се допуњава новим дигиталним публикацијама и формирају се нове целине. У Дигиталну БМС до краја маја 2016. године укупно је укључено 9338 публикација (833.735 дигиталних страница). ${ }^{4}$

Универзитетска библиотека „Светозар Марковић“ партнер је у пројектима Europeana Libraries (укључени дигитални садржаји из 19 водећих европских библиотека) и Europeana Newspapers (више од 10 милиона новинских станица у Europeani из 17 библиотека Европе).

Библиотека града Београда развила је дигиталну библиотекy dLibra од 2012. године. У колекцији је 651 дигитални објекат, док је у претходном временском периоду забележено 563.604 посета. ${ }^{5}$ На страници дигиталне библиотеке је линк на FBC он-лајн збирци пољских културних и научних институција са 2,7 милиона објеката ${ }^{6}$

Бројни пројекти дигитализације у Србији показују искуства и резултате на овом подручју, али већина од њих се развијала самостал-

3 http://www.digitalna.nb.rs/ (доступно 30.06.2016.)

http://digital.bms.rs/ebiblioteka/about (доступно 30.06.2016.)

http://dlibra.bgb.rs/dlibra (доступно 30.06.2016.)

http://fbc.pionier.net.pl/ (доступно 30.06.2016.) 
но, појединачно, без координације и уз примену различитих платформи и технолошких решења. Библиотеке у периоду 2003 - 2015. године презентирају своје нове дигиталне колекције на: Конференцијама SEEDI (South-Eastern European Digutization Initiative - Иницијатива за дигитализацијуујугоисточној Европи); Међународним конференцијама у региону и националним конференцијама у организацији NCD (Nacionalni centar za digitalizaciju), Математичког института САНУ и Математичког факултета Универзитета у Београду; Међународним конференцијама Филолошког факултета Универзитета у Београду.

Под утицајем Pulmanovih smernica Pulmanov digitalni vodič - Pulman smernice ${ }^{7}$ прве дигиталне збирке јавних библиотека у Србији имале су за циљ визуелизацију идентитета библиотеке на мрежи, презентацију и промоцију културне баштине из локалног окружења у глобалном окружењу. Временом су библиотечке колекције почеле допуњавање дигиталним примерцима које не поседују у физичком облику. Највеће промене биле су у формату докумената - промене миграције докумената из једног облика у други (папирни, микрофиш, микрофилм у електронски) обогатиле су завичајне збирке новим документима који су успоставили корелацију са традиционалним - папирним.

На порталима матичних јавних библиотека у Србији присутне су дигитализоване колекције из завичајних збирки: Народна библиотека Крушевац ${ }^{8}$, Градска библиотека „Владислав Петковић Дис“ “Чачак', Градска библиотека Суботица ${ }^{10}$, Народна библиотека „Илија М. Петровић“ Пожаревац ${ }^{11}$, Шабачка библиотека ${ }^{12}$ са 526 докумената у 30 збирки на 99.687 страна, Народна библиотека „Раде Драинац“ Прокупље ${ }^{13}$, Народна библиотека Бор ${ }^{14}$, Народна библиотека „Радослав Никчевић“ Јагодина, Библиотека „Стефан Првовенчани“ Краљево. Библиотека „Вук Караџић“ у Крагујевцу спроводи дигитализацију од 2011. године

7 Pulmanov digitalni vodič, http://www.matbibli.rs.ba/Download/PulmanPrevodFinal.pdf (доступно 30.06.2016.)

http://www.nbks.org.rs/digitalna-biblioteka, (доступно 30.06.2016.)

http://www.cacak-dis.rs/dig_bibl/index.html (доступно 30.06.2016.)

http://www.subiblioteka.rs/sr/digitalna-biblioteka/ (доступно 30.06.2016.)

http://digitalna.nb.rs/sf/NBS/Zavicajne_zbirke/Narodna_biblioteka_Pozarevac, (доступно 30.06.2016.)

http://www.bibliotekasabac.org.rs/www/digitalna.php (доступно 30.06.2016.)

http://www.bibliotekaprokuplje.org.rs/index.php/2012-06-18-20-32-12, (доступно 30.06.2016.)

http://www.digitalnizavicaj.com/ (доступно 30.06.2016.) 
и на мрежним страницама библиотеке је преко 11.000 страница из фонда Завичајне збирке, поменимо само часопис „Кораци“15. Градска библиотека „Карло Бјелицки“ Сомбор такође има развијену дигиталну

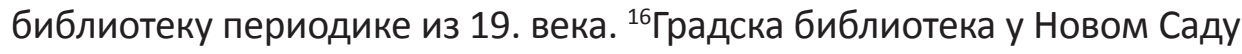
од 2013. године на веб страници развија дигиталну колекцију ${ }^{17}$

\section{Актуелни пројекти дигитализације у Србији}

Пројекат ДАРИJА Србија (DARIAH-RS), „,каодео паневропске Дигиталне истраживачке инфраструктуре за уметности и хуманистику, бави се осмишљавањем, имплементацијом и промоцијом истраживања, пројеката, алата и најбољих искустава на пољу дигиталних уметности и дигиталне хуманистике у Републици Србији и у ширем европском контексту. DARIAH је намењена истраживачима и институцијама које желе да: пронађу и користе истраживачке податке из целе Европе, размењују способности, знања, методологије и примере добре праксе у различитим доменима и дисциплинама, потврде да раде у складу са прихваћеним стандардима, експериментишу и сарађују на иновативним пројектима са другим истраживачима и институцијама." ${ }^{18}$ DARIAH повезује националне, регионалне и локалне подухвате у циљу стварања кооперативне инфраструктуре у којој се јасно уочавају комплементарности и заједнички формулишу нови изазови.

Одлуком Европске комисије, пројекту DARIAH је додељен статус Европског конзорцијума истраживачких инфраструктура (European Research Infrastructure Consortium, ERIC). Осим Србије, земље оснивачи DARIAH-ERIC-a су Аустрија, Белгија, Грчка, Данска, Ирска, Италија, Кипар, Луксембург, Малта, Немачка, Словенија, Француска, Холандија и Хрватска. Представничко тело Републике Србије у DARIAH-ERIC-y је Министарство културе и информисања. Национални представник је Народна библиотека док је национални координатор: Центар за дигиталне хуманистичке науке. На овај начин Народна библиотека

15 http://www.gbns.rs/ (доступно 30.06.2016.)

16 http://www.biblioso.org.rs/digitalna_zbirka.php?lng=сі (доступно 30.06.2016.)

17 http://www.gbns.rs/http://www.gbns.rs/ (доступно 30.06.2016.)

18 http://dariah.rs/o-\%D0\%BD\%D0\%B0\%D0\%BC\%D0\%B0/ (доступно 30.06.2016.) 
Србије је започела стварање националног агрегатора за Европеану. У току маја 2016. године у Музеју историје Југославије одржана је конференција „Дигитализација фото грађе“. У току је и дигитализација штампаних и рукописних речника ка изради дигиталне лексикографске инфраструктуре за српски језик.

Удружење истраживача института хуманистичких наука покренуло је иницијативу за стварање Интернет библиотеке Србије за хуманистичке науке и уметност ИБиС. Пројекат се реализује у сарадњи са Националним центром за дигитализацију ИБиС, у оквиру пројекта Виртуелна библиотека НЦД-а, чији је уредник др Жарко Мијајловић. „Циљ ИБиС је презентација српске научне и културне баштине и актуелне научне продукције хуманистичких и сродних наука широј публици - стручној и научној, домаћој и међународној јавности. Дигитализација националног научног и културног наслеђа и текуће научне продукције од великог је значаја не само за унапређење приступа овим садржајима и за међународну научну размену, већ и за очување културног идентитета, едукацију домаће јавности и представљање културних различитости у европској средини. “19

ИБиС представља дигиталну колекцију научних радова са отвореним (бесплатним и непосредним) приступом, урађену у складу са међународним стандардима европских дигиталних библиотека.

Интернет библиотека Србије за хуманистичке науке и уметност је обједињени портал дигиталних колекција више институција, међу којима су представљене следеће са избором дигитализованих наслова из својих научних области:

Математички институт САНУ - у колекцији електронских ресурca eLib омогућава приступ српским математичким часописима, као и Ревији Националног центра за дигитализацију. ${ }^{20}$

Балканолошки институт САНУ на својој веб страници у Интернет библиотеци у дигитализованој колекцији појединих наслова монографских публикација пружа на увид виртуелној заједници корисника и наслов Балканика - годишњак Балканолошког института. ${ }^{21}$

\footnotetext{
19 http://ibis.mi.sanu.ac.rs/index.html (доступно 30.06.2016.)

20 http://www.mi.sanu.ac.rs/novi_sajt/library/electronic_resources.php (доступно 30.06.2016.)

21 http://www.balkaninstitut.com/srp/internet-izdanja (доступно 30.06.2016.)
} 
Етнолошки институт САНУ је дигитализовао Појмовник српске културе. ${ }^{22}$

Дигитална библиотека Института за књижевност и уметност - у којој ду дигитализована издања Института - едиција Поетика истраживања, Српско усмено стваралаштво и монографије издате у скоријем периоду. ${ }^{23}$

\section{Законска регулатива}

Закон о библиотечко - информачионој делатности „Службени гласник PC“ (бр. 52 /11), члан 44. одређује да „Библиотека има обавезу да континуирано ради на дигитализацији библиотечко информационе грађе и извора као дела културног наслеђа Србије. Народна библиотекма Србије спроводи и координира послове на дигитализацији библиотечко - информационе грађе и извора у Републици Србији. Ближе услове за дигитализацију библиотечко - информационе грађе и извора прописује министар надлежан за културу."

Закон о старој и реткој библиотечкој грађи „Службени гласник PC" бр. (52 /11), у VI делу,Делатност заштите - одељак Микрофилмовање и дигитализација грађе, члан 27. став 3 одређује „Библиотеке су обавезне да категорисану стару и ретку библиотечку грађу дигитализују ради коришћења и представљања."

На основу члана 25. став 2 Закона о старој и реткој библиотечкој грађи (2011) министар културе је 16. марта 2013. године донео Правилник о мерама техничке заштите старе и ретке библиотечке грађе где се у делу Мере техничке заштите члан 2. став 1 наводи да је дигитализација једна од мера превентивне заштите, а став 3 дефинише да су „микрофилмовање и дигитализација процеси преформатирања старе и ретке библиотечке грађе."

Дигитализација библиотечких колекција је покренула бројна питања, а међу њима и питање ауторских права.

22 http://www.etno-institut.co.rs/cir/pojmovnik/pojmovnik.php (доступно 30.06.2016.)

23 Дигитална библиотека Института за књижевност и уметност http://www.ikum.org.rs/ (доступно 30.06.2016.) 


\section{Дигиталне колекције Универзитета у Београду}

Поједини факултети Београдског универзитета развијају дигиталне колекције. Једна од најбогатијих како квалитетним садржајем тако и бројем дигитализованих објеката је колекција Филолошког факултета Универзитета у Београду. По речима декана проф. др Александре Вранеш “Филолошки факултет Универзитета у Београду, баштинећи двестогодишњу традицију високог школства у Србији, видан и јединствен на образовној мапи Србије, па и Европе, по бројности језика који се на њему изучавају, својим ресурсима, кадром и интересовањима, као и свешћу о својим потребама определио се да оформи виртуелну библиотеку и стави је у функцију учења на даљину. Стога је Филолошки факултет започео процес дигитализације културне баштине прво сопствених издања, која су окосница научне мисли у областима изучавања 34 језика и њима припадајућих књижевности и култура, као и у областима библиотекарства, информатике, архивистике и музеологије. Спознајући ове друштвено-хуманистичке науке окосницом културе сваке земље, верујемо да електронска библиотека, која омогућава апсолутну претраживост свих текстова представља значајан допринос и наставном и научном процесу. Доступно је 107.000 страна изузетно важних издања: истакнутих периодичних публикација (Анала, Прилога, Књижевности и језика, Италике, Славистике, Годишњака Катедре за српску књижевност, Филолошког прегледа...), едиције докторских дисертација одбрањених на Филолошком факултету, зборника радова са међународних научних конференција, монографских публикација, антологија, збирки." 24

Друга велика дигитална колекција је дигитални репозиторијум докторских дизертација PHAIDRA ${ }^{25}$ Београдског универзитета, које су у отвореном приступу доступне од маја 2012. године преко веб страница Универзитетске библиотеке „Светозар Маарковић“. ${ }^{26}$

\footnotetext{
24 http://www.fil.bg.ac.rs/lang/sr/biblioteke/digitalna-biblioteka/ (доступно 30.06.2016.)

25 https://phaidrabg.bg.ac.rs (доступно 30.06.2016.)

26 http://ubsm.bg.ac.rs/latinica/strana/85/doktorske-disertacije (доступно 30.06.2016.)
} 


\section{Музејске колекције на мрежи}

Музеј историје Југославије МИЈ - један од најпосећенијих музеја у Србији - која документује друштвено - политичку активност Јосипа Броза Тита. Преко 150.000 црно-белих фотографија (формата $18 \times 24$ cm) і 800.000 негатива, показује све значајне догађаје од 1947. до 1980. године у којима је чествовао и присуствовао Јосип Броз. Фотографски су забележена Титова путовања у земљи и иностранству,посете страним/них шефовима држава и владам сусрети са светски познатим личностима из сфера јавног живота, моменти из свакодневног живота.Пројекат дигитализације фото грађе МИЈ представља сарадњу музејских, архивских и информационих стручњака у циљу изналажења нових приступа културном наслеђу. Активности на пројекту уључују истраживање и индексирање фотографија, заштиту музејске грађе кроз дигитализацију,развијање софтверских решења за обраду и онлајн интерактивни приступ материјалу,као и промоцију могућности које пројекат пружа истраживачима и широј заједници на мрежи. Сличан пројекат има и Народна библиотека Бор (велика збирка индустријске фотографије)

Музеј примењене уметности из Београда учествује у пројекту Europeana Fashion у коме 24 партнера из 12 европских змаља заједнички представљају историјат и развој европске моде, уз 700.000 дигитализованих цртежа, постера, видео материјала.

Југословенска кинотека је партнер у пројекту European Film Gateway који је укључио грађу 30 филмских архива у Europeanu. На порталу су доступнна 63 филма из Србије на тему балканских и Првог светског рата.

\section{Дигиталне колекције из региона - допуна националне културне баштине}

Дигиталне колекције националних библиотека из региона представљају велико богатство грађе која је on-line доступна и која је неопходна истраживачима, преваасходно из области друштвенин наука. У Словенији je dLib.sl присутна на мрежи од новембра 2005. 
године. ${ }^{27}$ Документ Стратегија развога словеначке диигиталне библиотеке 2007-2010. године дефинише да је Дигитална библиотека Словеније веб портал за управљање знањем. Друга велика дигитална колекција у Словенији је Kamra или дигитализована културна баштина словеначких региона. ${ }^{28}$

INFOBIRO digitalni arhiv је пример из Сарајева са више стотина похрањених текстова и континуираним растом уноса. Међутим ова дигитална колекција није у отвореном приступу већ се коришћење текстова наплаћује. ${ }^{29}$

Национална и свеучилишна књижница из Загреба развила је дигиталну библиотеку. Дигитализовану баштину чини избор значајних дела из фонда пренесених у дигитални облик. ${ }^{30}$ Старе хрватске новине - портал дигитализованих новина које су доступне од 2008. године - 146 наслова новина - 179.870 страница (август 2015) је важан on-line peсурс и у отвореном је приступу. ${ }^{31}$ Друга велика дигитална колекција je DAR дигитални аакдемски репозиторијум - садржи старе дисертације од 1880. до 1952. године из фонда, као и савремене магистарске тезе и докторате које су оставили аутори. ${ }^{32}$

\section{Проблеми дигитализације грађе у институцијама културе}

Бројни су проблеми са којима се сусрећу библиотекари при дигитализацији фондова и могуће их је генерализовати:

- Недостатак законске регулативе, Закон о библиотечкоинформационој делатности (2011) уводи дигитализацију у делатност као део обавезни део посла, док Правилник о дигитализацији до данас није званично објављен иако је Комисија одрадила свој део посла;

- Стандарди за јавне библиотеке у организационој структури јавних библиотека не предвиђају одељења за дигитализацију. У јавним библиотекама у Србији постоји неколико центара -

27 http://www.dlib.si/menu/o\%20nas (доступно 30.06.2016.)

28 http://www.kamra.si/en/album-of-slovenia.html (доступно 30.06.2016.)

29 http://www.infobiro.ba/ (доступно 30.06.2016.)

30 http://db.nsk.hr/ (доступно 30.06.2016.)

31 http://dnc.nsk.hr/newspapers/ (доступно 30.06.2016.)

32 http://dar.nsk.hr/ (доступно 30.06.2016.) 
Градска библиотека „Владислав Петковић Дис“ Чачак, Градска библиотека „Карло Бјелицки“ Сомбор и Библиотека града Београда:

- У оквиру систематизације послова Завичајних одељења на којима у већини библиотека ради један стручни радник, предвиђена је дигитализација фонда без увида у обим послова и техничку опремљеност истих;

Прва званична институционализована едукација библиотекара за послове дигитализације покренута је августа 2013. године у оквиру е-учионице преко веб странице Народне библиотеке Србије коју је покренуло Одељење за микрографију и дигитализацију Народне библиотеке Србије и наставак едукације у првој половини 2014. године и Непостојање јединственог Регистра дигитализоване грађе, да се послови не дуплирају.

Један од проблема је и недостатак стратегије дигитализације на националном нивоу. Стратегија дефинише начин и правила дигитализације музејске, архивске, библиотечке и судиовизуелне грађе према стандардима европске дигиталне библиотеке Europeane. Дигитализација културне баштине један је од инвестиционих приоритета европске стратегије 2020 године. Стратегијом се планира успостављање нове инфраструктуре што укључује успостављање мреже репозиторијума, агрегатора и доделу јединствених идентификатора дигиталним објектима, нове моделе пословања.

\section{Закључак}

На веб страницама музеја и архива углавном се налазе основне информације са подацима који се односе на актуелности, кратак опис збирки, изложби. На страницама музеја углавном је активан Facebook као један од видова популарисања локалне баштине, промоције дешавања и привлачења нових категорија корисника. У односу на поменуте институције библиотеке су у великој техничкој предности како и опреми тако и у запосленима који су активно прихватили императив доживотног учења и који имају знања, вештине и компетенције да одговоре захтевима у актуелном тренутку.

Схватајући потребу дигитализације колекција Министарство културе и информисања PC је на конкурсу за заштиту културне баштине за 2016. годину за област дигитализација културног наслеђа опре- 
делило средства у износу од 51.549.210,00 динара. На конкурс су пристигле 74 пријаве. Комисија је одабрала 34 пројекта - из библиотека, музеја, архива који треба да унапреде инфраструктуру институција - техничку опрему као и да резултирају предствљањем локалне културне баштине на вебу. ${ }^{33}$

\author{
Snežana Nenezić \\ National Library Kruševac
}

\title{
THE CULTURAL INSTITUTIONS IN THE ERA OF DIGITAL HUMANITIES
}

\section{Summary}

The present moment and highly developed technological environment have added a new dimension to the activity of cultural institutions, spread out, but are also imposed on traditional heritage institutions of culture of the new requirements.

The subject of this study was to compare digitizing collections of heritage institutions of culture : libraries, museums and archives in Serbia and their availability on the network.

Employees of cultural institutions are, on the one hand, users of the digital collection in order to professional training, supplementing descriptions to collections, and the collection by digital surrogates themselves, on the other hand they themselves are creators of content of institutions in which they work - digital collections.

Digital copies added the new value to the collections and require different "reading images" and realize a new correlation with the users - readers, viewers, researchers.

The visualization of collections has developed a new aesthetic and a new kind of reading.

Exploration the web sites of cultural institutions in Serbia, gives us a complete picture of the representation of different digital collections in a network environment, as well as the manner in which collection are presented, available and how users are aware of the existence thereof.

The subject of this paper is the relationship of books, articles, objects and documents in collections.

Key words: cultural institutions, digitization of collections, digital humanities

33 http://www.kultura.gov.rs/docs/konkursi/81653170029617522806/Re\%C5\%A1enje\%20 -\%20digitalizacija\%20kulturnog\%20nasle\%C4\%91a\%202016.pdf (доступно 30.06.2016.) 